\title{
Subglottic Cancer pTO TNM Finding v6 and v7
}

National Cancer Institute

\section{Source}

National Cancer Institute. Subglottic Cancer pTO TNM Finding v6 and v7. NCI Thesaurus. Code C64715.

Subg lottic cancer with no evidence of a primary tumor. (from AJCC 6th and 7th Eds.) 